\title{
Climate Change and the Conservation of Archaeological Sites: a Review of Impacts Theory
}

\author{
Caithleen Daly \\ Technological University Dublin, cathydaly@hotmail.com
}

Follow this and additional works at: https://arrow.tudublin.ie/beschrecart

Part of the Cultural Resource Management and Policy Analysis Commons, Environmental Sciences Commons, Historic Preservation and Conservation Commons, and the History of Art, Architecture, and Archaeology Commons

\section{Recommended Citation}

Daly, C.:Climate Change and the Conservation of Archaeological Sites: a Review of Impacts Theory Conservation and Management of Archaeological Sites, vol. 13, no. 4, 2011, p.293-310. doi:10.1179/ $175355212 \times 13315728646058$

This Article is brought to you for free and open access by the School of Surveying and Construction Management at ARROW@TU Dublin. It has been accepted for inclusion in Articles by an authorized administrator of ARROW@TU Dublin. For more information, please contact arrow.admin@tudublin.ie, aisling.coyne@tudublin.ie, gerard.connolly@tudublin.ie.

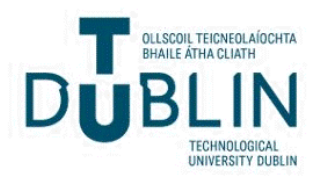




\title{
Climate Change and the Conservation of Archaeological Sites: a review of impacts theory
}

\section{CATHY DALY}

\author{
Dublin Institute of Technology
}

\begin{abstract}
This article identifies the current state of knowledge in the literature regarding the possible impacts of future climatic change on archaeological sites and ensembles. Drawing on the literature review a matrix of potential impacts is collated to provide a simplified overview. This theoretical 'menu' is then tested by applying it to a vulnerability assessment of the World Heritage site of Skellig Michael in Ireland. The case study results reveal some knowledge gaps, particularly in regard to the impacts of climate change on buried archaeological remains.
\end{abstract}

\section{KEYWORDS}

Climate change, archaeology, heritage, conservation, research

\section{INTRODUCTION}

There is a growing body of research which suggests that global climate change will impact (both positively and negatively) on cultural heritage resources. Attention has been focused on built heritage however, and very few studies consider archaeological sites or cultural landscapes. This paper presents the current state of knowledge, mainly in the English language literature, regarding climate change impacts on archaeological sites and monuments. By extrapolating from the literature to a case-study site in the Republic of Ireland the paper aims to highlight strengths and weaknesses of the current body of research. The impacts theory from the literature is collated into a matrix and applied to the case study site using an adapted eight step vulnerability methodology (Schröter, Polsky and Patt, 2005). The results demonstrate the usefulness of the matrix but also highlight a number of knowledge gaps in the literature particularly in regard to impacts on buried archaeological remains.

\section{DEFINING TERMS OF REFERENCE}

\section{ARCHAEOLOGICAL SITES \& ENSEMBLES}

The European Convention on the Protection of the Archaeological Heritage (1992) defines archaeology as 'all remains and objects and any other traces of mankind from past epochs...the preservation and study of which help to retrace the history of mankind and its relation with the natural environment;... for which excavations or discoveries and other methods of research into mankind and the related environment are the main sources of information' (Article 1).

Archaeological ensembles overlap to a great extent with cultural landscapes often having close associations with topographical features and impacting landscape development. 


\section{CUltural landSCAPES}

Defined by the World Heritage Operational Guidelines as properties that are representative of the 'combined works of nature and of man' and illustrate the 'evolution of human society and settlement over time, under the influence of the physical constraints and/or opportunities presented by their natural environment' etc. (Intergovernmental Committee for the Protection of the World Cultural and Natural Heritage, 2008). Cultural Landscapes that are identified as archaeological, or are intrinsically associated with archaeological remains, or whose preservation impacts on those remains, are included for consideration here.

\section{Climate Change PREDiCTIONS FOR IRELAND}

Projections for the coming century suggest Ireland will experience warmer, wetter winters and warmer, drier summers (McGrath and Lynch, 2008; Sweeney et al., 2003). There is likely to be an increase in the severity and incidence of extreme weather events. While mean wind speeds are not expected to change over the coming century the incidence of extreme cyclones (and thus wind and precipitation) is expected to increase due to changes in the Atlantic surface temperature (McGrath and Lynch, 2008). There will be some regional variations, summer temperatures will be highest in the south-east for example and the Atlantic coast is likely to see the greatest increase in storms. Sea Level Rise is estimated at $3.5 \mathrm{~cm} /$ decade around Ireland but with local variations due to geological activity (McGrath and Lynch, 2008; Edwards and O'Sullivan, 2007).

\section{CURRENT STATE OF KNOWLEDGE}

\section{OVERVIEW}

The literature on the subject of climate change and cultural heritage is rapidly expanding but little of it pre-dates the $21^{\text {st }}$ century. The earliest articles were concerned with raising awareness of the issue amongst heritage practitioners and this took over a decade to achieve. In 1996 Pearson and Williams wrote: '...there is a vast amount of information we have to gather about cultural places before we as archaeologists, anthropologists or heritage managers can have a proper input into the discussion about the possible effects of climate change. It will be very difficult to convince governments of the threats to the cultural environment, and of the range of options available to reduce the impact of climate change, if substantial work is not carried out in the next 10 years' (Pearson and Williams, 1996: 126). Unfortunately this statement has proved to be prophetic and cultural heritage is now playing catch up with other more pro-active sectors in terms of research and policy, and has yet to receive a mention in any of the four Assessment Reports by the Intergovernmental Panel on Climate Change (IPCC).

The approaches taken on climate change impacts for heritage are generally either thematic risk analyses (Kelly \& Stack, 2009; Cassar, 2005; Australian National University, 2009) or material specific studies (Bolton, 2007; Bonazza et al., 2009). Most of the studies take a strategic overview and most focus on the built environment. There are only a few that deal specifically with archaeology and landscapes and even less that take a detailed site specific approach (Kincey, Challis and Howard, 2008). 
Impacts discussed in the literature are frequently divided into direct weathering effects and indirect effects i.e. those caused by mitigation or adaptation strategies. Assessments of the sensitivity of heritage to these effects are largely dependent upon past experience of weathering and conservation science. The largest research project completed to date is the European Union funded Noah's Ark project ${ }^{1}$. They used predictions from regional climate models to produce maps for future heritage climatologies e.g. wet-frost cycles. By combining those predictive maps with existing knowledge of deterioration mechanisms Noah's Ark created a series of predictive maps, of damage and risk, for heritage materials (Sabbioni and Bonazza, 2010; Sabbioni, Brimblecombe and Cassar, 2010). UNESCO published two documents on the subject, one aimed at heritage professionals and the World Heritage community, and the other more accessible case studies intended to raise public awareness (Colette, 2007a; Colette, 2007b). At National level English Heritage and the National Trusts in the UK, the Heritage Council in Ireland and the Nordic group for Northern European countries are leading the way (Kelly \& Stack, 2009; English Heritage, 2008; National Trust, 2005b; Berghall and Pesu, 2008).

The work on built heritage is increasingly prolific; in particular there has been a substantial amount of work carried out on stone weathering and climate change impacts (Bolton, 2007; Bonazza et al., 2009; Smith, Warke and Curran, 2004; Viles 2002). Although most of the studies refer to intact buildings rather than archaeological remains, the theory is often applicable to both. Changes in weathering patterns (e.g. reduced freeze-thaw or increased salt cycling) are mapped by Noah's Ark for European heritage. Other concerns are for the increased frequency of severe storms and intense rainfall leading to more frequent flood events (possible erosion or subsidence of foundations). Wind throw has also been identified as a danger to ruined buildings and excavated archaeology (Cassar, 2005; 23). For stone in general prolonged periods of wetness will have implications for a number of decay mechanisms including salts and biological action (Bolton, 2007; Smith et al., 2004).

The bias in the literature towards built heritage is understandable given that it is the most visible and quantifiable heritage resource. Buildings are also easily understandable to policy makers and the public and have a tangible value that makes research into their preservation an easier sell. It would be a mistake however, to assume that these most visible remains of our past are the most threatened. The burial conditions under which archaeology can be preserved are sensitive to disturbance and even minor environmental alterations may disrupt the equilibrium of the system thereby triggering deterioration mechanisms. In addition, changes in landscape use and character will impact on the integrity of many archaeological ensembles, both physically and aesthetically. To consider the literature on impacts to archaeology in more detail sub-soil deposits (rural), landscape features and coastal sites are taken independently.

\section{BURIED ARCHAEOLOGY}

There are relatively few articles where the issues relating to sub-surface archaeology and climate change impacts are elucidated fully. This may be due to poor understanding of burial preservation and the impact of environmental changes on this process (Cassar, 2005: 26; Van de Noort, Chapman and Cheetham, 2001; Holden et al., 2006), or to the major problem of how to deal with a risk that is largely unquantifiable given the many unknown sites that are threatened (Caffrey and Beavers, 2008). The difficulties in predicting impacts of a changing environment 
are also compounded by a lack of funding for research into in situ preservation (Van de Noort et al., 2001).

Archaeologists expressed most concern for the vulnerability of anaerobic waterlogged environments (associated with high levels of preservation for organic artefacts and palaeological evidence) to climate change (Cassar, 2005: 89). Studies on the contemporary effects of water abstraction due to quarrying and agriculture demonstrate that it results in destruction of organic remains, soil shrinkage and building subsidence. Predictions for drier summers are therefore of grave concern for sites with good organic preservation (Howard et al., 2008). There is less research on the effect of changes to the water quality or chemistry, caused by altered recharge rates, but it has been established that maintenance of the anoxic environment (benign to organic remains) depends on micro-organisms that are sensitive to even small alterations in water properties (Chapman, 2002; Nord, Mattson and Tronner, 2005; Holden et al., 2006). In Nordic countries increasing annual precipitation may mean soils become more waterlogged and therefore have better preservation conditions. The exact effects of altered rainfall on groundwater recharge depends on factors such as soil, vegetation, rainfall amount and frequency (Chandler, 2008). There will therefore be large regional and local variations in the effects of climate change on groundwater and in turn on archaeological preservation conditions. Drying of soils is likely to compromise stratigraphy through cracking and heave, the most dramatic effects being in areas where differences between summer and winter rainfall volumes are predicted to increase (Cassar 2005). When the soil dries out and cracks the penetration of oxygen will occur causing rapid microbial action and the oxidation of metals (Riksantikvaren, 2010).

While many sites, including underwater archaeology, may be exposed by increased erosion some may also be buried by silt and debris carried by flood waters (Pearson and Williams, 1996; Kelly $\&$ Stack, 2009). The potential benefit of this for the protection of sites is not explored in the literature. In addition erosion is likely to lead to the discovery of some new sites and materials, a positive development but only if there are resources available to record the information. In Jutland a survey after a storm in 1999 found 17\% of archaeological sites had suffered loss, partly from the storm and partly from the cleaning up operations (Riksantikvaren, 2010). In Sweden a severe storm in January 2005 resulted in damage to almost one third of all the archaeological sites in the affected area including 1,500 prehistoric burial sites (Berghall and Pesu, 2008). These examples demonstrate that archaeological remains, even prehistoric sites, are vulnerable to storm related damage.

Increased soil temperature is mainly seen as a problem in Polar Regions where the permafrost that previously preserved organic materials is now melting (Gheyle, 2009; Egloff, 2006). Freeze thaw cycling can cause ground heave and subsidence and is set to increase in Northern latitudes (Colette, 2007a). In southern Finland there is concern that the heavy machinery used in forestry could become very damaging if the ground is no longer frozen when they operate over archaeological deposits (Berghall and Pesu, 2008). Melting of ice results in the loss of environmental data held within the layers of frozen water but conversely the thawing of snow and ice has already resulted in numerous discoveries of archaeological material (Riksantikvaren, 2010). In the High Alpine area of Scandinavia organic objects from as far back as 4,000 BCE have been discovered. This material will rapidly decompose after exposure thus it represents both a future opportunity and future challenge for archaeologists. 
The problem with many of the impacts outlined is that they are completely speculative. This would seem to be unavoidable given the futuristic nature of the issue and the invisibility of the resource in question. One attempt at a more quantitative approach was taken by researchers developing a computer model to simulate the impact of future climate change on the archaeological resource of two river catchments (Trent and Ouse) (Kincey et al., 2008; Howard et al., 2008). The models' conclusions are in line with those above, whether this validates the theory is debatable however, given that the computer model is also reliant on the same limited knowledge base.

\section{LANDSCAPE}

Effects due to climate change may manifest through agricultural practices or ecosystems responses such as plant distribution; the loss or gain of species; or changes to growing seasons (Sweeney et al., 2002). While there may be a lack of specific monitoring at cultural heritage properties, the utilization of research from other fields can be of great value. Reports on shifts in agricultural practices, forestry or population densities for example are often carried out by environment agencies and are relevant to the archaeological values in the landscape (Sweeney et al., 2003). Changes in agricultural practices and field use will lead to changes in the rural landscape (Berghall and Pesu, 2008). With increasing competition from agriculture and a growing population the sustainability of water supplies in some rivers may become an issue during the summer and autumn (Kelly \& Stack, 2009) and is likely to increase the pressures on landscapes and wetland sites (Cassar, 2005). Increased drought may reduce vegetation cover, lead to wildfires and threaten archaeological landscapes (Australian National University, 2009; National Trust, 2005b). In Australia there is concern for social and spiritual elements of the landscape such as scarred and carved trees (Pearson and Williams, 1996; Pearson et al., 1998). In some areas loss of plant cover will lead to the risk of erosion of open or sub-surface archaeology, particularly when combined with intense rainfall (Pearson and Williams, 1996). High winds are also a concern for cultural landscapes and when combined with waterlogged soils are a particular risk to trees as roots become less secure (Riksantikvaren, 2010). Increased atmospheric concentrations of carbon dioxide (CO2) are likely to accelerate plant growth in some climates, potentially increasing root penetration that damages archaeological deposits (National Trust, 2005b).

Landslides, ground heave and subsidence are phenomena likely to occur more frequently due to intense rainfall or increased glacial melts (Colette, 2007a). In Ireland bog-bursts are likely to be more frequent (Sweeney et al., 2008). Due to unique environmental conditions peat lands preserve an invaluable record of human and environmental activity (National Trust, 2005b). In Ireland bogs reveal the most spectacular and important archaeological finds such as the Faddan More Psalter (http://www.museum.ie/). The increasing destruction of peat lands due to hotter drier summers, fires and erosion from heavy rain has serious consequences for both natural and cultural heritage.

Human adaptation responses may be equally as damaging to the landscape as climate change itself (Kincey et al., 2008; Howard et al., 2008; Egloff, 2006). Those responses include flood risk management e.g. dredging, improvements to storm drains; agriculture e.g. deeper root 
penetration by new crops, forestry reaching higher ground, increasing irrigation; and leisure and tourism damage through infrastructural requirements.

\section{COASTAL ARCHAEOLOGY}

The most severe losses due to climate change are likely to occur at the coast (National Trust, 2005a; Caffrey and Beavers, 2008; Edwards and O'Sullivan, 2007; Cuffe Fitzgerald, 2010; Murphy, Thackray and Wilson, 2009), Rowlands refers to it as the 'battlefront' (Rowland, 2008). Coastal heritage includes land based sites, intertidal sites and underwater or submerged sites including wrecks. The main threats are sea level rise (SLR), storm events and increased wave energy, leading to greater flooding, coastal erosion, coastal squeeze and saline intrusion (Pearson, 2008; Pearson and Williams, 1996). As coastal erosion and SLR progresses more monuments will find themselves within this extreme environment (Bolton, 2007; McNeary, 2010). Tidal influences are liable to be felt at the higher reaches of river systems and high tides combined with SLR and increased storm surges could cause significant flooding in previously immune areas (Chapman, 2002). The impacts will vary dependant on coastal morphology (Edwards and O'Sullivan, 2007), however for heritage in low lying coastal areas, on reclaimed land or near the high water mark there are serious concerns.

In a series of reviews by the National Trust (England, Wales and Northern Ireland) regional and site specific data for accelerating coastal erosion was gathered and possible future impacts on its coastal estates assessed (National Trust Northern Ireland, 2007; National Trust, 2005a; National Trust Wales, 2007). The Trust estimates that in England $60 \%$ of the coastline in their ownership is likely to suffer erosion with $10 \%$ of this being 100 to 200 metres inland (National Trust 2005a). The same pamphlet states that 500 archaeological and historic monuments will be at risk from coastal change over the next 100 years in addition to an unknown number of unexcavated sites. In Orkney the problem of coastal erosion of archaeology is so acute that appeals have been made to the local community to carry out recording (Berenfeld, 2008). In Ireland Edwards and O'Sullivan have looked at coastal and estuarine archaeology in some detail using casestudies to illustrate how coastal change results in the loss of archaeological heritage at an alarming rate (Edwards and O'Sullivan, 2007). In the Pacific a survey of cyclone damage to archaeological sites found that greater frequency of these events led to increased destruction because there was no recovery time i.e. for protective re-deposition of sediment or re-growth of vegetation (Spennemann, 2004). The paradox for archaeologists is that while coastal change will ultimately result in destruction of the sites, in the short term the erosion is exposing the richness of the resource in the intertidal zone (Edwards and O'Sullivan, 2007).

For underwater archaeology it is expected that wrecks may be exposed more frequently than before by the extreme weather but that in turn it could inhibit their documentation and excavation (Kelly \& Stack 2009). Increased deterioration of underwater wood is predicted as erosion of protective sediments exposes it to oxygenated water and exacerbate existing bacterial action (Bjordal, Nilsson and Klaassen 2006). The $\mathrm{pH}$ of the oceans is another concern for underwater preservation. Historically sea water has an average value of 8.0, dropping to 7.9 in the last century. Due to increasing levels of atmospheric $\mathrm{CO} 2$ a drop to as low as 7.4 in polar and sub-polar waters is predicted (a level unknown for 20 million years) (Riksantikvaren, 2010). Surprisingly the potential impact of this on underwater archaeology has not been tackled in the 
literature though the phenomenon itself is well established due to extensive research on coral reefs.

It has been suggested that dealing with competing and conflicting demands for the protection of coastal assets will become a major challenge for archaeologists in the future (Kelly \& Stack, 2009). Estuaries, coastal plains and wetlands, areas at most risk from SLR, tend to be rich in archaeology as well as modern urban settlements (Department of Environment and Local Government, 2001; Edwards and O'Sullivan, 2007). Adaptation strategies such as coastal defences and flood engineering are likely to affect cultural heritage on coasts and waterways (Kelly \& Stack, 2009; Murphy et al., 2009). Inappropriate interventions, spurred by public concern over land loss, can lead to changes in erosion and sedimentation patterns (Edwards and O'Sullivan, 2007). Even the more environmentally sensitive soft-engineering options are also problematic for coastal heritage which may be modified, buried or destroyed. It is important to note that coastal change, like the other natural phenomena discussed above, is caused by a myriad of factors. Although many authors make a link between observed coastal changes and climate change, this cannot as yet be proven (Flatman, 2009).

\section{IMPACTS MATRIX}

While there is a great deal of agreement in the literature over possible impacts, the complexities and uncertainties involved tend to overshadow this. In an attempt to address this lack of clarity a visual cause-effect matrix has been designed, focusing on the main predicted impacts for archaeological heritage in temperate climates (Table 1). Tables along similar lines have been created elsewhere using longer more comprehensive formats (Cassar et al., 2006; Kelly \& Stack, 2009). The aim here was to produce a simplified representation of the complex interactions discussed in the literature, a one page reference. Although the matrix does not address issues specific to non-temperate climates, the structure could be adapted for any region.

\section{CASE STUDY}

The matrix provides a menu of potential risks associated with climatic change on a regional basis; however management of these risks will occur at local level. In order to understand how individual sites will be impacted it is necessary to consider the values being protected, the nature of the site and the climate predictions for that locale. In the following case study the impacts matrix is utilized for a vulnerability assessment of the World Heritage Site of Skellig Michael to predicted future climate change.

\section{SITE DESCRIPTION AND VALUES}

Skellig Michael is one of two World Heritage sites in the Republic of Ireland. It was added to the World Heritage list in 1996 under criteria (iii) and (iv) as an outstanding example of an Early Christian monument. The monastic remains are located on a precipitous rock in the Atlantic, $11.6 \mathrm{~km}$ from the coast of county Kerry (Figure 1). The island is also home to breeding colonies of many species of bird, some of which are protected and endangered. The main monastic enclosure on the north peak is built on man-made terraces and consists of dry stone walls, beehive huts, two boat shaped oratories, a later mortar built church and a collection of stone 
cross slabs (Figure 2). The monastery is still reached today by one of the three original dry stone staircases that are all largely intact. In addition there is a hermitage on the more inaccessible south peak consisting of a number of small terraces and dry stone structures. The predominant stone of construction is Devonian sandstone, available on the island.

\section{Future Climate at SKellig Michael}

Traditional meteorological measurements and those produced by climate models do not normally provide all the information required for heritage conservation such as relative humidity or time of wetness measurements (Brimblecombe, 2010). Climate models are also problematic in terms of scale and at site level resolution there is much less confidence in their accuracy. The Irish Climate Analysis and Research Unit (ICARUS) project produced future data for Ireland using three different models and then combined these into a Multi-Ensemble Global Climate Model (GCM) to produce the mean of the three. The results tend to underestimate precipitation as it is difficult to capture the upper values for this (Rowan Fealy, pers. com.). Table 2 is compiled from ICARUS data and contrasts the Hadley and Multiple Ensemble model outputs for the meteorological station of Valentia Observatory (approximately $28 \mathrm{kms}$ north-east of Skellig Michael) for the periods 1961 to 1990 and 2070 to 2099. Although the consensus is that rainfall will increase in winter/autumn this is not expressed in the regional predictions (as seen in Table 2). Ocean models suggest that the frequency of extreme storm surge events at sea and extreme wave heights are likely to increase with a $25 \%$ increase in frequency and $10 \%$ increase in max height predicted on the south-west coast (McGrath and Lynch, 2008). One can conclude from the data that the future climatic parameters of most concern for Skellig Michael will be a reduction in summer rainfall and increased severity of storms with associated intense wind, rain and wave action. The reduction in freeze thaw events is positive but as the incidence of this is already low any reduction has limited significance. The increase in temperature is likely to impact upon the natural heritage more than cultural remains although it is not clear what the outcome of this will be for the value of the site. There is evidence already of a change in the availability of fish species in waters around the island, possibly due to rising sea temperatures, and of the nesting birds changing their diet accordingly (Bob Harris, pers. com., Office of Public Works, 16.8.2010). It might be the case that the importance of the Skelligs for avian preservation will increase due to negative impacts on breeding sites elsewhere. Should this happen it could add to existing restrictions on maintenance and conservation work to structures in nesting areas, compromising the resilience of the cultural heritage.

\section{ASSESSING VULNERABILITY}

The selection by management of successful strategies to address climate change impacts will depend on an informed assessment of the risks. In order to understand how the impacts matrix applies to an individual site, and crucially to identify for decision makers what are likely to be the key impacts, a site assessment is necessary. UNESCO recommends the use of a coupled human-environment vulnerability analysis for site level assessments (Colette 2007b). This requires evaluating the exposure $(\mathrm{E})$, sensitivity $(\mathrm{S})$ and adaptive capacity $(\mathrm{AC})$ of the site to the likely impacts of climate change. The AC of any system is its ability to cope with or recover from impacts and can be inherent or applied i.e. due to policies. In order to examine these three interacting factors a simple model in table format (Table 3) was developed by adapting 
Schröter's eight step methodology (Daly, 2008; Daly, 2009; Schröter et al., 2005). The vulnerability model was used to examine each heritage value in relation to the impacts hypothesized to be most pertinent. The data inputted into the table was based on information gathered from research and stakeholder interviews. Where quantifiable indicators were available these helped to attribute a value. In many cases suitable indicators are not available and stakeholder feedback was used as a means to verify the final results.

$\mathrm{AC}, \mathrm{S}$ and $\mathrm{E}$ were attributed numerical values from 1(low) to 3(high). The 'Measure of Vulnerability' was then calculated, positive values indicated the degree of vulnerability and negative values the facility for resilience. The advantage of this analysis is its holistic approach, requiring assessment of both human and environmental influences on the site. In the case of Skellig Michael the choice of impacts to be examined was determined from the matrix and above climate predictions. The complete vulnerability analysis is not reproduced here, but Table 4 illustrates how the model was applied in two examples.

This is an expert driven method that produces a qualitative ranking of impacts for the site. It is based on documentary evidence, field research and discussions with staff. The results provide an indication of future priorities but must be kept under review and supported wherever possible by scientific monitoring as they are inherently subjective.

\section{DISCUSSION}

The matrix provides a menu of possible impacts for consideration in a vulnerability assessment. Deciding which impacts may be of concern in a specific case requires an understanding of the site and its management. Site specific knowledge from stakeholders and experts is vital in the application of the impacts theory to practise. For example, as it is completely in State ownership, Skellig Michael is not subject to any agricultural practices. By contrast the impact of visitors is a major current concern for Skellig Michael, numbers are currently limited during the season to 180 per day (Department of Environment Heritage and Local Government, 2008) but there is on-going pressure to relax these restrictions. A climate change report in Northern Ireland (Arkell, Darch and McEntee, 2007) predicts an increase in summer tourism as the season becomes drier and warmer. If climate change brings a lengthening of the tourist season and greater visitor numbers it could place extra strain on management systems. The steep slopes and shallow soil cover on the island mean that erosion can be a problem especially around visitor routes. Increased desiccation followed by heavy rain would therefore be another impact of concern. The level of organic preservation in the archaeological layers on the island is quite poor however and it is therefore unlikely that drier summers will impact greatly on this resource.

The matrix represents the most common impacts of concern mentioned in the literature with the exception of some issues for extreme climates (i.e. melting permafrost or desertification). It takes a generalized approach and the case study application highlighted the existence of gaps. For example, due to its terrain and location, the impact of extreme weather on the health \& safety of visitors and on the ability of staff to conduct conservation works would be of major concern at Skellig Michael (Figure 3). While this may be a minority issue not detailed in the literature, at site level it is very significant and must be monitored. Anecdotal evidence suggests access to the island has become more problematic over the last $4-5$ years due to changes in the direction of 
the prevailing winds. Although this is not attributable to climate change, it demonstrates the disruption possible in a future where high seas and severe storms are more common.

Conducting the case study assessment highlighted another issue not mentioned in the literature, namely the lack of engagement of many heritage professionals with this topic. There is a level of uncertainty as to the severity or relevance of climate change impacts and when combined with scarce resources the result is the prioritization of more immediate problems. Given the current lack of evidence, the general wooliness of impacts theories and the underlying problem of an unquantifiable resource (i.e. the buried archaeology) it will be hard to alter this position.

\section{CONCLUSION}

Collating the literature on impacts into a matrix for the case study analysis provided an overview of current theory regarding climate change effects on archaeology. Combining this with climate models and local knowledge facilitated a preliminary assessment of vulnerabilities for the case study site of Skellig Michael. The application of current theoretical knowledge to a practical case study site illustrated some strengths and weaknesses of the literature. Gaps in the research available were identified, due in the main to the extreme generality of the published analyses. While the existing literature is valuable in providing a point of departure and a conceptual framework, there is a lack of specificity (i.e. case studies, scientific research and long-term monitoring) with which to develop the research convincingly. In the case of built heritage the scientific foundation has been provided by studies such as the International Co-operative Programme on effects on materials (ICP) and the Buildings Research Establishment (Viles et al., 2002) amongst others (Turkington et al., 2003). To some extent cultural landscapes can draw upon environmental studies for scientific data relating to waterways, coastal change, vegetation and so on (Sweeney et al., 2003; Pearson et al., 1998; Department of Environment and Local Government, 2001). In the case of subterranean heritage however, there are existing and acknowledged gaps in research and understanding of the burial environment per se (Van de Noort et al., 2001; Holden et al., 2006). The difficulty is to foresee how researchers can grapple successfully with researching an unquantified resource, preserved in poorly understood environmental conditions, that faces an uncertain level of climatic change. It is unsurprising perhaps that the literature fails to offer any solutions; nonetheless it is a challenge that must be taken up if we are to preserve the world's archaeological heritage for future generations.

\section{ACKNOWLEDGEMENTS}

The research presented here was gathered as part of doctoral work generously funded by ABBEST at Dublin Institute of Technology. Thanks are due to the staff of the OPW for their support and contributions to the case study, to Peter Brimblecombe for instigating this article and the reviewers whose comments improved it. 


\begin{tabular}{|c|c|c|c|c|}
\hline \multirow[t]{2}{*}{ Climate Effect } & \multirow[t]{2}{*}{ Controlling parameters } & \multicolumn{3}{|c|}{ Potential Impact on Heritage Values } \\
\hline & & Cultural Landscape & Structures \& Features & Buried deposits \\
\hline $\begin{array}{ll} & \text { TEMPERATURE } \\
\text { Increased annual } \\
\text { temperatures } \\
\text { - } \\
\text { Reduction in } \\
\text { freeze thaw events }\end{array}$ & $\begin{array}{l}\text { Temperature } \\
\text { Moisture }\end{array}$ & $\begin{array}{l}\text { Change (i.e. loss \&/or } \\
\text { gain) of habitats \& } \\
\text { species } \\
\text { Lengthening of } \\
\text { growing season } \\
\text { Changes in land use }\end{array}$ & $\begin{array}{l}\text { Increased biological } \\
\text { growth } \\
\text { Changes in lichen } \\
\text { colonies } \\
\text { Reduction in freeze } \\
\text { thaw weathering }\end{array}$ & $\begin{array}{l}\text { Accelerated micro- } \\
\text { biological activity } \\
\text { Changes in land use } \\
\text { (incr. arable farming } \\
\text { leading to plough } \\
\text { damage) }\end{array}$ \\
\hline $\begin{array}{ll} & \text { RAIN } \\
- & \text { Storms/heavy rain } \\
- & \text { Prolonged wet } \\
& \text { periods } \\
\text { - } & \text { Flooding } \\
\text { - } & \text { Altered water } \\
& \text { table } \\
\text { - } & \text { Prolonged dry } \\
\text { periods* }\end{array}$ & $\begin{array}{l}\text { Rain intensity \& } \\
\text { duration } \\
\text { Rain volume } \\
\text { Catchment hydrology } \\
\text { (i.e. flooding can be } \\
\text { caused by rain } \\
\text { elsewhere) } \\
\text { Temperature }\end{array}$ & $\begin{array}{l}\text { Soil erosion } \\
\text { Silting of river beds } \\
\text { Change/loss of habitats } \\
\text { \& species } \\
\text { Loss of vegetation } \\
\text { Deterioration of water } \\
\text { quality } \\
\text { Landslides } \\
\text { Changes in irrigation } \\
\text { practice* } \\
\text { Deterioration of peat } \\
\text { lands* } \\
\text { Increased risk of fires* } \\
\text { Increased recreational } \\
\text { use* }\end{array}$ & $\begin{array}{l}\text { Mechanical erosion } \\
\text { Dissolution } \\
\text { Change in humidity } \\
\text { cycles (salts) } \\
\text { Increase in time of } \\
\text { wetness (leading to } \\
\text { biological colonization) } \\
\text { Rising damp } \\
\text { Subsidence \& collapse } \\
\text { Changes in surface } \\
\text { deposition \& washing } \\
\text { of pollutants } \\
\text { Increased recreational } \\
\text { use* }\end{array}$ & $\begin{array}{l}\text { Mechanical erosion } \\
\text { Changes in soil } \\
\text { chemistry \& pH } \\
\text { Subsoil instability } \\
\text { Loss of stratigraphic } \\
\text { integrity } \\
\text { Eutrophication } \\
\text { accelerating biological } \\
\text { decay } \\
\text { Dessication of } \\
\text { waterlogged organic } \\
\text { deposits* }\end{array}$ \\
\hline \multirow[t]{2}{*}{$\begin{array}{ll} & \text { WIND } \\
\text { - } & \text { Wind driven rain } \\
\text { - } & \text { Wind pressure } \\
& \text { Wind driven } \\
\text { - } & \text { particulates } \\
& \text { Gusts \& changes } \\
\text { in wind direction. }\end{array}$} & $\begin{array}{l}\text { Wind speed } \\
\text { Wind direction } \\
\text { Rain intensity \& } \\
\text { duration }\end{array}$ & $\begin{array}{l}\text { Soil erosion } \\
\text { Tree throw }\end{array}$ & $\begin{array}{l}\text { Mechanical erosion \& } \\
\text { abrasion } \\
\text { Dissolution } \\
\text { Increased penetration } \\
\text { of water (leading to salt } \\
\text { movement) } \\
\text { Increased loading } \\
\text { pressure } \\
\text { Physical damage \& } \\
\text { collapse }\end{array}$ & $\begin{array}{l}\text { Erosion of earthen } \\
\text { monuments/soil cover } \\
\text { Physical damage from } \\
\text { tree throw }\end{array}$ \\
\hline & & \multicolumn{3}{|c|}{ Additional Coastal Impacts } \\
\hline $\begin{array}{ll} & \text { INCREASED } \\
\text { SEA } \\
\text { TEMPERATURE } \\
\bullet \quad \text { Sea Level Rise } \\
\bullet \quad \text { Cyclones }\end{array}$ & $\begin{array}{l}\text { Temperature } \\
\text { Ocean currents }\end{array}$ & $\begin{array}{l}\text { Coastal flooding } \\
\text { Erosion } \\
\text { Salt in soils and water } \\
\text { table } \\
\text { Migration of human } \\
\text { population } \\
\text { Tree throw } \\
\text { Coastal protection } \\
\text { engineering }\end{array}$ & $\begin{array}{l}\text { Erosion } \\
\text { Salt water intrusion \& } \\
\text { rising damp } \\
\text { Increase in salt damage } \\
\text { Storm damage }\end{array}$ & $\begin{array}{l}\text { Erosion of sites } \\
\text { (exposure \&/or loss) } \\
\text { Sedimentation of sites } \\
\text { Salt water intrusion } \\
\text { Submersion } \\
\text { Coastal protection } \\
\text { engineering }\end{array}$ \\
\hline $\begin{array}{ll} & \text { COASTAL } \\
& \text { WINDS } \\
\text { - } & \text { Wind transported } \\
& \text { salts } \\
\text { - } & \text { Wind driven sand } \\
\text { - } & \text { Increased wave } \\
& \text { heights } \\
\text { - } & \text { Storm surge }\end{array}$ & $\begin{array}{l}\text { Wind speed } \\
\text { Wind direction } \\
\text { Surface pressure }\end{array}$ & $\begin{array}{l}\text { Erosion of sand dunes } \\
\text { Coastal erosion } \\
\text { Saline intrusion } \\
\text { Flooding }\end{array}$ & $\begin{array}{l}\text { Increased penetration } \\
\text { of salts \& salt } \\
\text { weathering } \\
\text { Sand blasting } \\
\text { Flooding } \\
\text { Erosion of foundations }\end{array}$ & $\begin{array}{l}\text { Exposure \&/or erosion } \\
\text { of sites in sand dunes, } \\
\text { underwater and } \\
\text { intertidal areas } \\
\text { Saline intrusion } \\
\text { Flooding }\end{array}$ \\
\hline
\end{tabular}

Table 1. Impacts Matrix for the predicted effects of climate change on archaeological heritage in temperate zones 


\begin{tabular}{|c|c|c|c|c|c|}
\hline Period & \begin{tabular}{|l|} 
Average \\
Temperature \\
(derived from \\
min and max \\
values) \\
\end{tabular} & $\begin{array}{l}\text { No. of Freeze } \\
\text { events (i.e. } \\
\text { non- } \\
\text { consecutive } \\
\text { days < }<\text { C } \\
\end{array}$ & \begin{tabular}{|l} 
Average \\
monthly \\
Summer \\
Rainfall \\
(July) \\
\end{tabular} & \begin{tabular}{|l} 
Average \\
monthly \\
Winter \\
Rainfall \\
(December) \\
\end{tabular} & $\begin{array}{l}\text { Intensity of } \\
\text { Rainfall } \\
\end{array}$ \\
\hline \multicolumn{6}{|c|}{ GCM Ensemble Model output } \\
\hline 1961-1990 & $10.5^{\circ} \mathrm{C}$ & 1.06 & $77.5 \mathrm{~mm}$ & $152 \mathrm{~mm}$ & \begin{tabular}{|l}
16 (days \\
$>10 \mathrm{~mm} / \mathrm{yr})$
\end{tabular} \\
\hline 2070-2099 & $\begin{array}{l}12.8^{\circ} \mathrm{C} \\
=\uparrow 2.3^{\circ} \mathrm{C}\end{array}$ & $\mid \begin{array}{l}0 \\
=\downarrow \downarrow 100 \%\end{array}$ & $\begin{array}{l}50.6 \mathrm{~mm} \\
=\downarrow 35 \%\end{array}$ & $\begin{array}{l}153 \mathrm{~mm} \\
=\uparrow 0.6 \%\end{array}$ & $\begin{array}{l}13 \text { (days } \\
10 \mathrm{~mm} / \mathrm{yr}) \\
=\downarrow 18.5 \%\end{array}$ \\
\hline \multicolumn{6}{|c|}{ Hadley Model output } \\
\hline 1961-1990 & $10.5^{\circ} \mathrm{C}$ & 4.3 & $83.5 \mathrm{~mm}$ & $147.4 \mathrm{~mm}$ & \begin{tabular}{|l}
$27($ days \\
$p 10 \mathrm{~mm} / \mathrm{yr})$
\end{tabular} \\
\hline 2070-2099 & $\begin{array}{l}12.5^{\circ} \mathrm{C} \\
=\uparrow 2^{\circ} \mathrm{C}\end{array}$ & $\begin{array}{l}1.5 \\
=\downarrow \\
=\downarrow 55 \%\end{array}$ & $\begin{array}{l}46.8 \mathrm{~mm} \\
=\downarrow 44 \%\end{array}$ & $\begin{array}{l}146 \mathrm{~mm} \\
=\downarrow 0.9 \%\end{array}$ & \begin{tabular}{|l}
25 (days \\
$>10 \mathrm{~mm} / \mathrm{yr})$ \\
$=\downarrow 7.4 \%$
\end{tabular} \\
\hline
\end{tabular}

Table 2. Comparison of GCM Ensemble model with the Hadley model for Valentia Observatory under the A2 emissions scenario. Derived from projections provided by ICARUS (courtesy of R. Fealy, National University of Ireland, Maynooth)

\begin{tabular}{|l|l|l|l|l}
\hline Matrix Input & Exposure (E) & Sensitivity (S) & $\begin{array}{l}\text { Adaptive } \\
\text { Capacity (AC) }\end{array}$ & $\begin{array}{l}\text { Measure of } \\
\text { Vulnerability } \\
\text { (V) }\end{array}$ \\
\hline $\begin{array}{l}\text { Impact of } \\
\text { concern }\end{array}$ & 1 to 3 & 1 to 3 & 1 to 3 & $\mathrm{~V}=(\mathrm{E}+\mathrm{S})-\mathrm{AC}$ \\
\hline
\end{tabular}

Table 3. Framework model for site specific evaluations of vulnerability to climate change impacts (Daly, 2008: 20) 


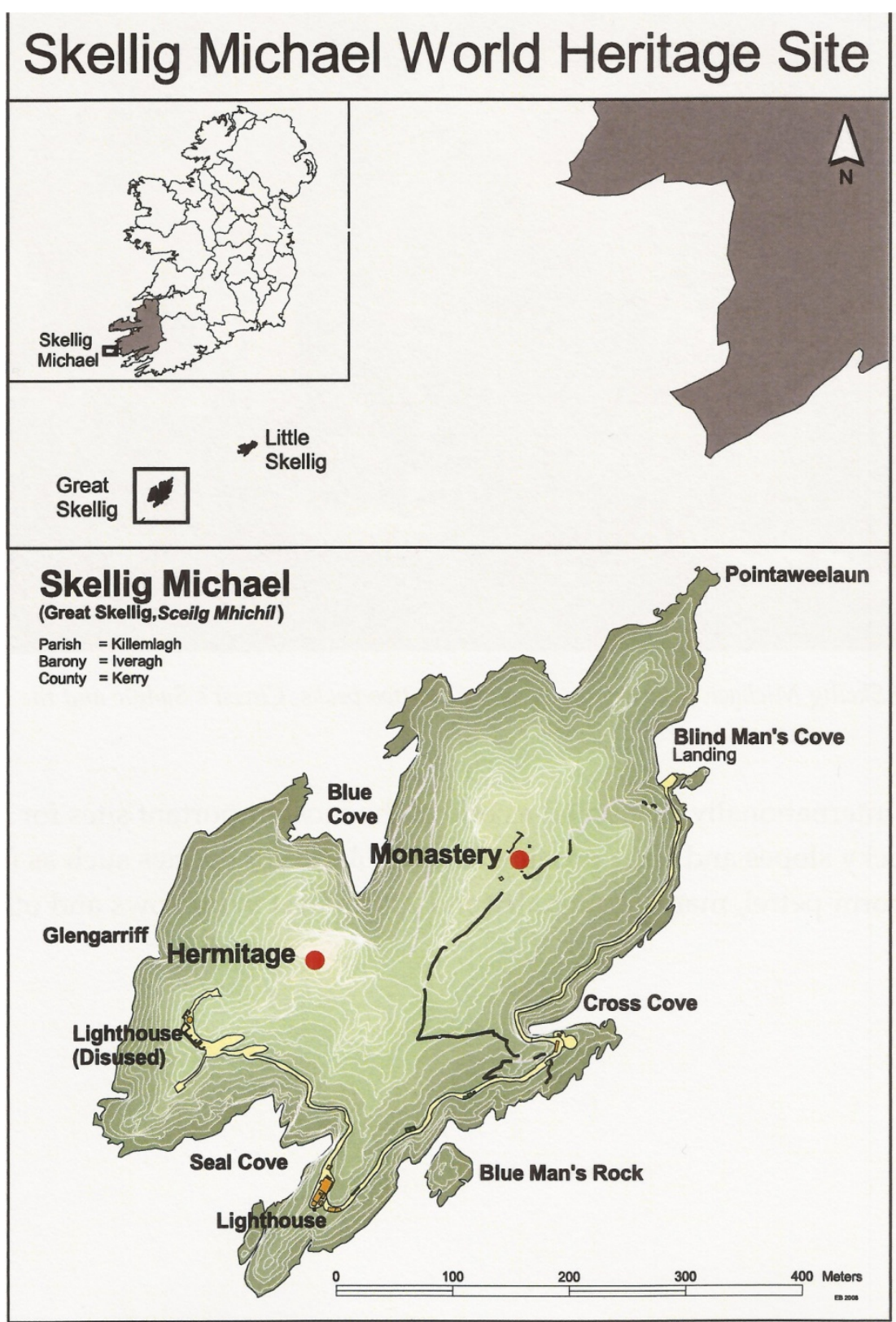

FIGURE 1. Site location and survey of island of Skellig Michael showing the main elements (Department of Environment Heritage and Local Government 2008) 


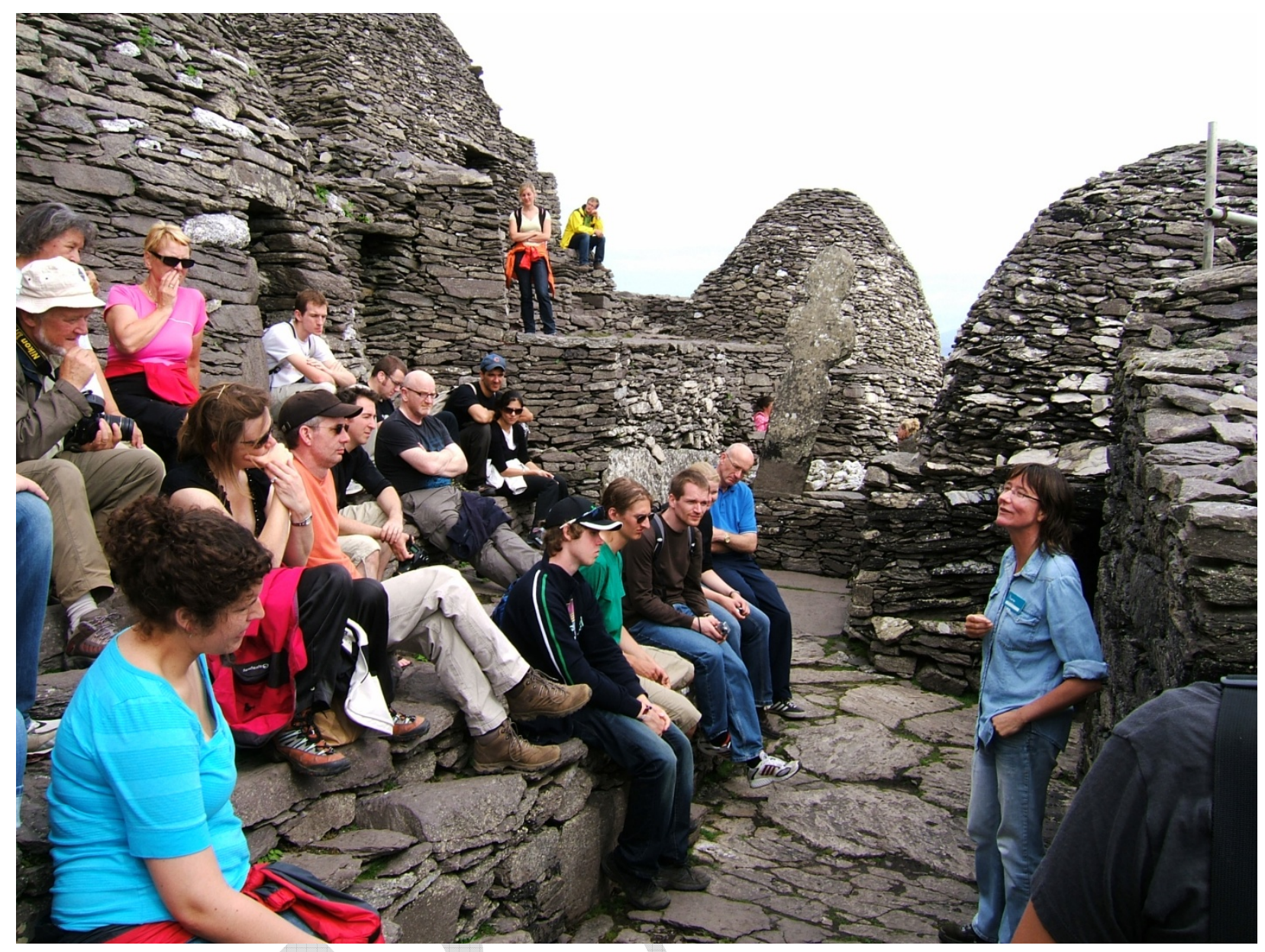

FIGURE 2. Tourists in the main monastic enclosure of Skellig Michael August 2010

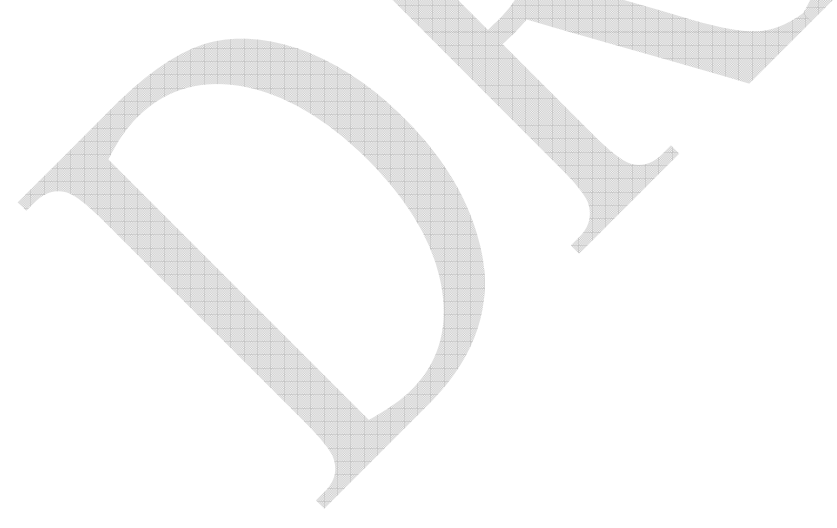




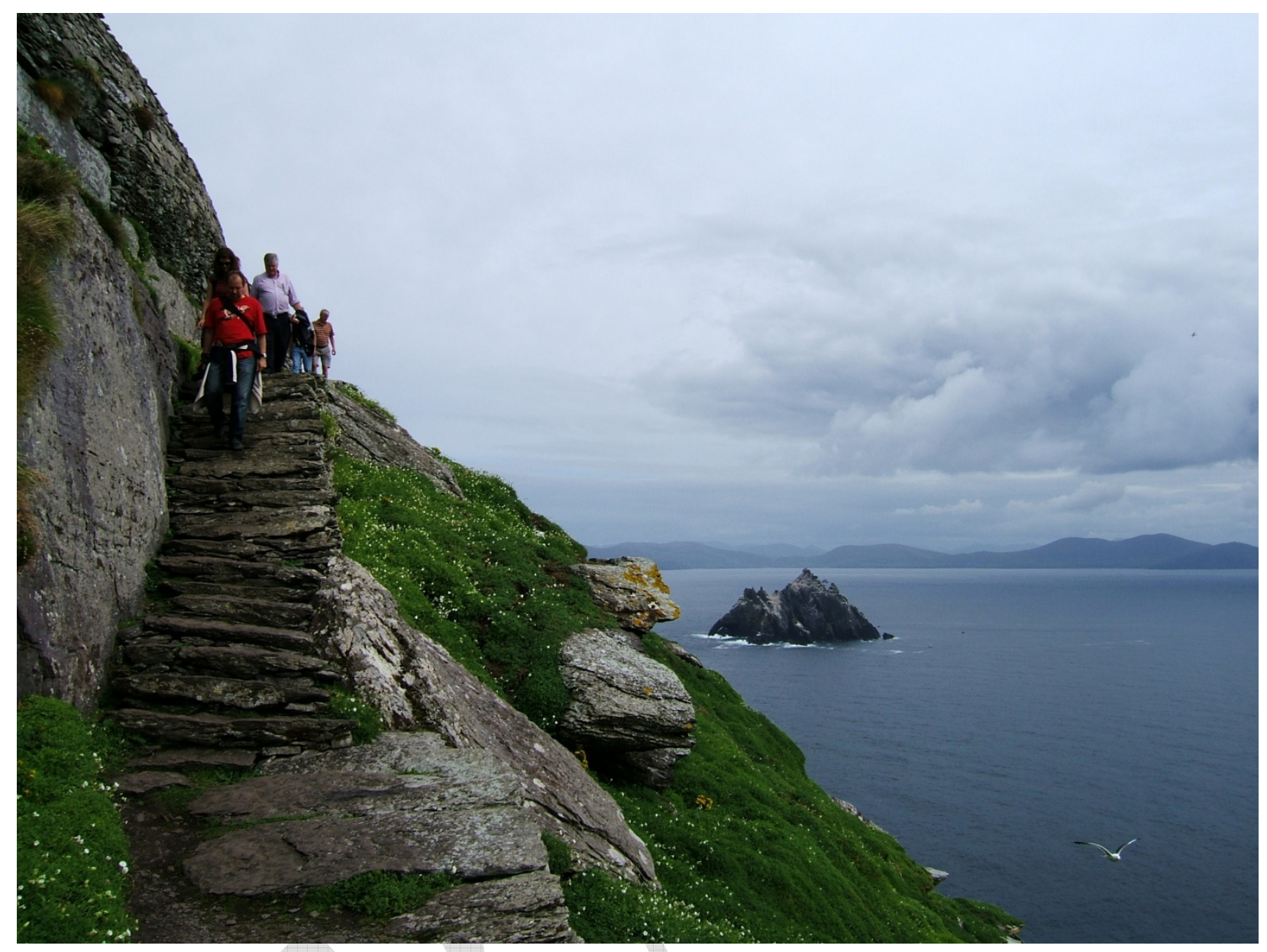

FIGURE 3. The steep topography and Medieval staircases that characterize Skellig

\section{Michael}

\section{NOTES ON CONTRIBUTOR}

Cathy Daly studied archaeology at Trinity College Dublin (BA) and objects conservation at the University of Wales, Cardiff (BSc). After working for many years as an archaeological conservator Cathy returned to full time education and is currently undertaking doctoral research at the Dublin Institute of Technology. The title of her $\mathrm{PhD}$ is Measuring and Monitoring Impacts of Climate Change on Ireland's World Heritage.

Correspondence to: Cathy Daly, 53 Portside, Rosslare Harbour, Co. Wexford, Ireland. Email: cathydaly@hotmail.com 


\section{REFERENCES}

Arkell, B., Darch, G. \& McEntee, P. eds. 2007. Preparing for a changing climate in Northern Ireland. Final Report of Project UKCC13. Edinburgh: Sniffer.

Australian National University. 2009. Implications of climate change for Australia's World Heritage properties: A preliminary assessment. A report to the Department of Climate Change and the Department of the Environment, Water, Heritage and the Arts by the Fenner School of Environment and Society, the Australian National University. Canberra: Australian Government.

Berenfeld, M. L. 2008. Climate Change and Cultural Heritage: Local Evidence, Global Responses. The George Wright Forum, 25: 66-82.

Berghall, J. \& M. Pesu. 2008. Climate Change and the Cultural Environment; Recognized Impacts and Challenges in Finland. The Finnish Environment Series, 44en. Helsinki: Ministry of the Environment.

Bjordal, C. G., Nilsson, T. \& R. Klaassen. 2006. Bacterial Destruction of Wooden Cultural Heritage. In: M. Drdacky \& M. Chapuis, eds. Proceedings of the $7^{\text {th }}$ European Conference Safeguarded Cultural Heritage. Prague: Glos Semily, pp. 9-16. Available at: <www.arcchip.cz>

Bolton, J. 2007. Potential Impacts of Climate Change on the Decay \& Soiling of Irish Building Stone. Unpublished report for the Heritage Council of Ireland.

Bonazza, A., Messina, P., Sabbioni, C., Grossi, C. M. \& Brimblecombe, P. 2009. Mapping the impact of climate change on surface recession of carbonate buildings in Europe. Science of the Total Environment, 407: 2039-2050.

Brimblecombe, P. 2010. Heritage Climatology. In: R. A. Lefevre \& C. Sabbioni, eds. Climate Change and Cultural Heritage. Bari: Edipuglia, pp. 49-56.

Caffrey, M. \& Beavers, R. 2008. Protecting Cultural Resources in Coastal U.S. National Parks from Climate Change. The George Wright Forum, 25: 86-97.

Cassar, M. 2005. Climate Change and the Historic Environment. London: University College London Centre for Sustainable Heritage.

Cassar, M., Young, C., Weighell, T., Sheppard, D., Bomhard, B. \& Rosabel, P. 2006. Predicting and Managing the Effects of Climate Change on World Heritage: A joint report from the World Heritage Centre, its Advisory Bodies, and a broad group of experts to the 30th session of the World Heritage Committee (Vilnius 2006). Paris: UNESCO World Heritage Centre.

Chandler, D. 2008. Water supplies could be strongly affected by climate change. MIT News Office [accessed 3 November 2010]. Available at: <http://web.mit.edu/newsoffice/2008/agugroundwater-1218.html> 
Chapman, H. P. 2002. Global Warming: The Implications for Sustainable Archaeological

Resource Management. Conservation and Management of Archaeological Sites, 5: 241-245.

Colette, A. 2007a. Case Studies on Climate Change and World Heritage. Paris: UNESCO World Heritage Centre.

Colette, A. 2007b. Climate Change and World Heritage: Report on predicting and managing the impacts of climate change on World Heritage and Strategy to assist States Parties to implement appropriate management responses. World Heritage Report No. 22. Paris: UNESCO World Heritage Centre.

Cuffe Fitzgerald, A. 2010. Climate Change and Shoreline Built Cultural Assets; The Preparation of a Vulnerability Atlas. Unpublished report for the Heritage Council.

Daly, C. 2008. Climate Change and World Heritage: A vulnerability Assessment of Brú na Bóinne, Ireland. Unpublished thesis submitted for a Masters of Arts in World Heritage Studies. Cottbus: Brandenburg Technical University.

Daly, C. 2009. Analysing the Vulnerability of World Heritage to Climate Change; a Case Study of Brú na Bóinne, Ireland. Unpublished paper delivered at the 5th annual Ename Colloquium; Climates of Heritage, Ostend.

Department of Environment and Local Government. 2001. Coastal Zone Management. Dublin: Spatial Planning Unit, Department of Environment and Local Government.

Department of Environment, Heritage and Local Government. 2008. Skellig Michael World Heritage Site Management Plan 2008-2018. Wexford: Department of Environment, Heritage and Local Government.

Edwards, R. \& O'Sullivan, A. 2007. A Vulnerability Asessment of Ireland's Coastal Archaeological Heritage. Unpublished final report for the Heritage Council: Archaeology Grant (Ref: TRINI 382).

Egloff, B. 2006. Archaeological Heritage Management, Climate Change and World Heritage in the 21st Century. In: M. Petzet \& J. Ziesemer, eds. Heritage at Risk; ICOMOS World Report 2006/2007. Altenburg Germany: E. Reinhold-Verlag, pp. 200-202.

English Heritage. 2008. Climate Change and the Historic Environment. London: English Heritage.

Fealy, R. \& Sweeney, J. 2007. Statistical downscaling of precipitation for a selection of sites in Ireland employing a generalised linear modelling approach. International Journal of Climatology, 27: 2083-2094.

Flatman, J. 2009. A Climate of Fear: Recent British Policy and Management of Coastal Heritage. Public Archaeology, 8: 3-19. 
Gheyle, W. 2009. The Frozen Tombs of the Altay Mountains, Climate Change and Tourism: Mapping the Archaeological Heritage of Altay. Unpublished paper delivered at the $5^{\text {th }}$ Ename Colloquium: Climates of Heritage Conservation Ostend.

Holden, J., West, L. J., Howard, A. J., Maxfield, E., Panter, I. \& Oxley, J. 2006. Hydrological controls of in situ preservation of waterlogged archaeological deposits. Earth Science Reviews, 78: 59-83.

Howard, A. J., Challis, K., Holden, J., Kincey, M. \& Passmore, D. G. 2008. The impact of climate change on archaeological resources in Britain: a catchment scale assessment. Climatic Change, 91: 405-422.

Intergovernmental Committee for the Protection of the World Cultural and Natural Heritage. 2008. Operational Guidelines for the Implementation of the World Heritage Convention. Paris: UNESCO World Heritage Centre.

Kincey, M., Challis, K. \& Howard, A. J. 2008. Modelling selected implications of potential future climate change on the archaeological resource of river catchments: an application of geographical information systems. Conservation and Management of Archaeological Sites, 10: 113-131.

McGrath, R. \& Lynch, P. eds. 2008. Ireland in a Warmer World; Scientific Predictions of the Irish Climate in the Twenty-First Century. Dublin: Community Climate Change Consortium for Ireland [accessed 22 September 2009]. Available at <http//www.c4I.ie>

McNeary, R. 2010. Riverine Archaeology in Ireland and the Shannon: Past, Present and Future Directions. Unpublished paper delivered at Working together better for the Shannon 2010, Heritage Council seminar, Carrick on Shannon.

Murphy, P., Thackray, D. \& Wilson, E. 2009. Coastal Heritage and Climate Change in England: Assessing threats and priorities. Conservation and Management of Archaeological Sites, 11: 915.

National Trust. 2005a. Shifting Shores: Living with a Changing Coastline. London: The National Trust.

National Trust. 2005b. Review of the UK Climate Change Programme: A response by the National Trust to the Government's consultation paper [accessed 9 August 2010]. Available at: $<$ http://www.nationaltrust.org.uk/main/w-climate_change-programme_response_mar05.pdf>

National Trust Northern Ireland. 2007. Shifting Shores: Living with a Changing Coastline. Ballynahinch, Co. Down: The National Trust.

National Trust Wales. 2007. Shifting Shores: Living with a Changing Coastline. Cardiff: The National Trust. 
Nord, A. G., Mattson, E. \& Tronner, K. 2005. Factors influencing the long-term corrosion of bronze artefacts in soil. Protection of Metals, 41: 339-346.

Pearson, M., Johnston, D., Lennon, J., McBryde, I., Marshall, D., Nash, D. \& Wellington, B. 1998. Environmental indicators for national state of the environment reporting - Natural and Cultural Heritage. Australia: State of the Environment Environmental Indicator Reports. Canberra: Department of the Environment.

Pearson, M. \& Williams, E. 1996. Possible effects of climate change on the cultural national estate. In L. Smith \& A. Clarke, eds. Issues in Management Archaeology. Tempus Volume 5. St Lucia: Anthropology Museum, University of Queensland, pp.123-127.

Riksantikvaren. 2010. English summary; Facts about and prognoses for climate change which affect cultural heritage in Nordic countries. In: Effekter av klimaendringer på kulturminner og kulturmilj申, Delrapport 3 [accessed 3 November 2010]. Available at: <http//www.ra.no>.

Rowland, M. 2008. Saving the past from the future. Historic Environment, 21: 19-29.

Sabbioni, C. \& Bonazza, A. 2010. How mapping Climate Change for Cultural Heritage? The Noah's Ark Project. In R.-A. Lefevre \& C. Sabbioni, eds. Climate Change and Cultural Heritage. Bari: Edipuglia, pp. 37-42.

Sabbioni, C., Brimblecombe, P. \& Cassar, M. 2010. The Atlas of Climate Change Impacts on European Cultural Heritage: Scientific Analysis and Management Strategies. London: Anthem Press.

Schröter, D., Polsky, C. \& Patt, A. G. 2005. Assessing vulnerabilities to the effects of Global Change: an eight step approach. Mitigation and Adaptation Strategies for Global Change, 10: 573-596.

Smith, B. J., Warke, P. A. \& Curran, J. M. 2004. Implications of climate change and increased 'time-of-wetness' for the soiling and decay of sandstone structures in Belfast, Northern Ireland. In R. Prikryl, ed. Dimension Stone 2004; New Perspectives for a Traditional Building Material. London: Taylor \& Francis, pp. 9-14.

Spennemann, D. H. R. 2004. Conservation management and mitigation of the impact of tropical cyclones on archaeological sites. In D. H. R. Spennemann \& D. W. Look, eds. Disaster Management Programs for Historic Sites. San Francisco \& Albury: Association for Preservation Technology, Charles Sturt University, pp. 113-132.

Sweeney, J., Donnelly, A., McElwain, L. \& Jones, M. 2002. Climate Change Indicators for Ireland. Wexford: Environmental Protection Agency.

Sweeney, J., T., Brereton, T., Byrne, C., Charlton, C., Emblow, R., Fealy, R., Holden, N., Jones, M., Donnelly, A., Moore, S., Purser, P., Byrne, K., Farrell, E., Mayes, E., Minchin, D., Wilson, J. \& Wilson, J. 2003. Climate Change, Scenarios \& Impacts for Ireland. Wexford: 
Environmental Protection Agency, Ireland [accessed 11 December 2007]. Available at $<$ www.epa.ie>

Sweeney, K., Fealy, R., McElwain, L., Siggins, L., Sweeney, J. \& Trinies, V. 2008. Changing Shades of Green. The environmental and cultural impacts of climate change in Ireland. The Irish American Climate Project [accessed 9 February 2010]. Available at <www.irishclimate.org>

Kelly, B. \& Stack, M. eds. 2009. Climate Change, Heritage and tourism: Implications for Ireland's Coast and Inland Waterways. Kilkenny: The Heritage Council.

Turkington, A. V., Martin, E., Viles, H. A. \& Smith, B. J. 2003. Surface change and decay of sandstone samples exposed to a polluted urban atmosphere over a six year period: Belfast, Northern Ireland. Building and Environment, 38: 1205-1216.

Van de Noort, R., Chapman, H. P. \& Cheetham, J. L. 2001. In situ preservation as a dynamic process: the example of Sutton Common, United Kingdom. Antiquity, 75: 405-22.

Viles, H. A. 2002. Implications of future climate change for stone deterioration. In S. Siegesmund, T. Weiss \& A. Vollbrecht, eds. Natural Stone Weathering Phenomena, Conservation Strategies and Case Studies. London: Geological Society, pp. 407-418.

Viles, H. A., Taylor, M. P., Yates, T. J. S. \& Massey, S. W. 2002. Soiling and decay of N.M.E.P. limestone tablets. The Science of the Total Environment, 292: 215-229.

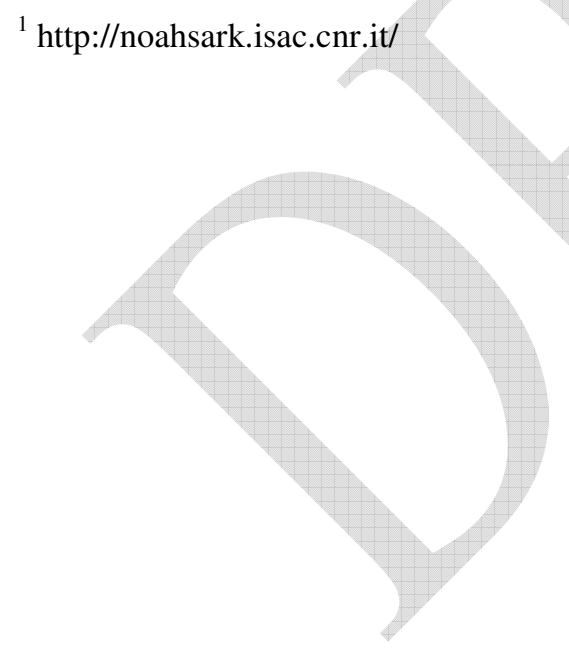

